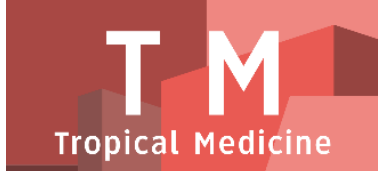

PAPER - OPEN ACCESS

\title{
Gambaran Penyembuhan Luka Tikus Diabetes Dengan Fraksi Etil Asetat Daun Binahong (Anredera cordifolia (Tenore) Steenis)
}
Author
: Trie Yuni Elfasyari
DOI
: 10.32734/tm.v1i3.282
Electronic ISSN
: 2623-0542
Print ISSN

$$
\text { : 2623-0550 }
$$

Volume 1 Issue 3 - 2018 TALENTA Conference Series: Tropical Medicine (TM)

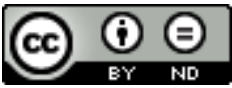

This work is licensed under a Creative Commons Attribution-NoDerivatives 4.0 International License.

Published under licence by TALENTA Publisher, Universitas Sumatera Utara
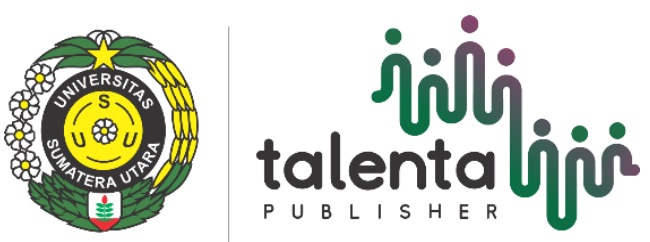


\title{
Gambaran Penyembuhan Luka Tikus Diabetes Dengan Fraksi Etil Asetat Daun Binahong (Anredera cordifolia (Tenore) Steenis)
}

\author{
Trie Yuni Elfasyari ${ }^{*}$, Kintoko $^{\mathrm{b}}$, Nurkhasanah $^{\mathrm{c}}$ \\ aProgram Studi Sarjana Farmasi Sekolah Tinggi Ilmu Kesehatan Mitra Bunda Persada, Batam, Kepulauan Riau 29444, \\ ${ }^{b c}$ Fakultas farmasi, Universitas Ahmad Dahlan, Yogyakarta \\ trieelfasyari@gmail.com
}

\begin{abstract}
Abstrak
Proses penyembuhan luka kulit dipengaruhi oleh kondisi dibetes mellitus (DM). Ekstrak etanol daun binahong dilaporkan dapat mempercepat penyembuhan luka tikus diabetes melalui mekanisme reepitelisasi dan kolagenasi. Penelitian ini dilakukan untuk mengetahui gambaran penyembuhan luka diabetes fraksi etil asetat daun binahong (Anredera cordifolia (Ten.) Steenis) konsentrasi $10 \%$ dengan parameter jumlah sel fibroblast pada tikus yang diinduksi sterptozotocin. Metode fraksinasi yang digunakan fraksinasi bertingkat padat cair dengan pelarut etil asetat yang bersifat semipolar. Penelitian eksperimental menggunakan 20 ekor tikus Wistar jantan usia 2 bulan, berat badan antara 150-200 gram yang diinduksi streptozotocin (STZ) dosis tunggal $45 \mathrm{mg} / \mathrm{kgBB}$ i.p. Punch biopsy digunakan untuk membuat luka pada kulit tikus dengan diameter $5 \mathrm{~mm}$ setelah kadar glukosa darah (KGD) di atas 250 $\mathrm{mg} / \mathrm{dL}$. Hewan uji dibagi menjadi 4 kelompok, terdiri dari kontrol sehat (tanpa induksi STZ dan tanpa perlakuan), kontrol negatif (biocream), kontrol positif (madecassol), dan fraksi etil asetat daun binahong 10\% (dalam biocream). Aplikasi topikal dilakukan 2 kali sehari sebanyak $25 \mathrm{mg}$ selama 10 hari pada area luka dan sekitarnya. Pengamatan dilakukan secara makroskopis dan mikroskopis. Penelitian menunjukkan bahwa fraksi etil asetat daun binahong mengandung senyawa flavonoi dan tanin, serta berperan dalam meningkatkan jumlah sel fibroblast $(\mathrm{P}<0.05)$.
\end{abstract}

Kata kunci: Binahong, Luka diabetes, Penyembuhan luka, Fibroblast

\begin{abstract}
The healing process of skin wounds is affected by the condition of diabetes mellitus (DM). Ethanol extract of binahong leaf is reported to accelerate the healing of diabetic rat wounds through the mechanism of reepitelisasi and collagenasi. This study was conducted to determine the wound healing image of diabetic fraction of ethyl acetate of binahong leaf (Anredera cordifolia (Ten.) Steenis) $10 \%$ concentration with parameters of fibroblast cell count in rats induced streptozotocin. The fractionation method used in liquid-density precipitation fraction with a semipolar ethyl acetate solvent. experimental study, using 20 male Wistar rats aged 2 months, weight between 150-200 grams induced streptozotocin (STZ) single dose $45 \mathrm{mg} / \mathrm{kgBB}$ i.p. punch biopsy is used to make skin lesions of mice with a diameter of $5 \mathrm{~mm}$ after blood glucose (KGD) levels above $250 \mathrm{mg} / \mathrm{dL}$. The test animals were divided into 4 groups, consisting of healthy control (without STZ induction and without treatment), negative control (Biocream), positive control (madecassol), and aethyl acetat fraction of binahong 10\% (in bioceam). Topical application performed twice of daily as much as $25 \mathrm{mg}$ for 10 days on the wound and surrounding areas. Observations were made macroscopically and microscopically. The results showed that contained compounds flavonoids and tannins, and plays a role in increasing the number of fibroblast cells $(\mathrm{P}<0.05)$.
\end{abstract}

Keywords: Binahong, Diabetic injury, Wound healing, Fibroblast. 


\section{Pendahuluan}

Luka diabetes merupakan luka yang sering terjadi pada penderita diabetes dengan gejala umum hiperglikemi yang kronis sehingga menimbulkan kerusakan pada organ [1,2]. Proses penyembuhan luka melibatkan hubungan yang rumit antara faktor seluler, humoral dan unsur jaringan ikat. Fase penyembuhan luka terdiri dari fase inflamasi, proliferasi dan maturasi yang masing-masing saling berkaitan [2]. Fibroblast merupakan sel terpenting dalam proses remodelling penyembuhan jaringan yang rusak. Fibroblast merupakan komponen seluler primer dari jaringan ikat dan sumber sintetis utama dari matrik protein [3].

Tanaman binahong (Anredera cordifolia (Ten.) Steenis) tersebar di daerah tropis dan subtropis, salah satunya Indonesia [4]. Penelitian aktivitas daun binahong dalam penyembuhan luka telah banyak dilakukan. Daun segar binahong dapat menyembuhkan luka eksisi pada kelinci [5]. Ekstrak heksan daun binahong dapat mempercepat penyembuhan luka diabetes tikus dengan meningkatkan reepitelisasi, kolagenasi dan menurunkan sel radang limfosit [6]. Gel ekstrak etanol daun binahong dengan konsentrasi 10\% dan $30 \%$ efektif menyembuhkan luka diabetes tikus yang diinduksi aloksan dengan parameter penutupan luka [7].

Senyawa kimia alkaloid, flavonoid, tanin, steroid, dan triterpen, telah diteliti terdapat di dalam daun binahong [8]. Ekstrak daun binahong masih banyak mengandung senyawa kimia kompleks sehingga perlu dilakukan fraksinasi. Fraksi etil asetat daun binahong mengandung flavonoid, saponin, dan steroid [9]. Etil asetat merupakan pelarut semipolar yang mampu menyari senyawa-senyawa yang bersifat antibakteri seperti flavonoid polihidroksi dan fenol [10]. Penggunaan etil asetat dalam menyari senyawa kimia dalam ekstrak daun binahong sebagai penyembuhan luka diabetes belum dilaporkan.

Berdasarkan latar belakang tersebut, penelitian ini menggunakan fraksi etil asetat daun binahong yang diperoleh dari ekstrak etanolik daun binahong untuk mengetahui gambaran penyembuhan luka tikus diabetes yang diinduksi STZ. Pembuatan fraksi dikombinasi basis biocream dengan konsentrasi $10 \%$.

\section{Bahan dan Metode}

Bahan yang digunakan dalam penelitian ini adalah daun binahong (Anredera cordifolia (Ten.) Steenis). Hewan uji tikus wistar jantan (dari laboratorium farmakologi universitas Sanata Dharma), etanol 96\% (Brataco®), n-heksan $\left(\right.$ Brataco $\left.{ }^{\circledR}\right)$, kloroform (Brataco®), etil asetat (Brataco®), aquadest, biocream (Merck $\left.{ }^{\circledR}\right)$, madecassol $\left(\right.$ Corsa $\left.{ }^{\circledR}\right)$, streptozotocin (Nacalai tesque $\left.{ }^{\circledR}\right)$, ketamin injeksi (Generik $\left.®\right)$, reagen glukosa GOD FS (Diasys $®$ ), formalin (Brataco®), set warna Hematoxylin-Eosin, pelat KLT Silika gel 60F254 (Merck®).

Alat-alat yang digunakan dalam penelitian diantaranya oven (Memmert $\left.{ }^{\circledR}\right)$, blender (National $\left.{ }^{\circledR}\right)$, ayakan 40 mesh, neraca analitik (Ohauss $®$ ), electric stirrer, corong Buchner, vakum, rotary evaporator (Heidolph ${ }^{\circledR}$ ), waterbath (Memmert ${ }^{\circledR}$ ), alat gelas (Pyrex $\left.{ }^{\circledR}\right)$, kandang individual, biochemistry analyzer (Ceretium NB-201®), micropipette, punch biopsy, spidol permanen, jangka sorong, mikroskop cahaya (Olympus BX 51®).

Penelitian ini menggunakan metode true experimental untuk mengetahui gambaran penyembuhan luka tikus diabetes dengan menggunakan fraksi etil asetat daun binahong $10 \%$. Penelitian dilakukan di Laboratorium Penelitian Terpadu Universitas Ahmad Dahlan.

\subsection{Fraksinasi dan Identifikasi Senyawa Fitokimia}

Fraksinasi dilakukan dengan metode padat-cair menggunakan beberapa pelarut yang berbeda. Fraksinasi menggunakan ekstrak etanol daun binahong dengan pelarut n-heksan, hasil residu di fraksinasi lebih lanjut menggunakan kloroform. Selanjutnya residu hasil kloroform difraksinasi kembali menggunakan pelarut etil asetat, sehingga diperoleh fraksi etil asetat daun binahong. Kandungan senyawa fitokimia diidentifikasi dengan KLT menggunakan campuran fase gerak kloroform-metanol-air (6:3,3:0,7) dilakukan terhadap flavonoid, polifenol, dan saponin.

\subsection{Induksi Diabetes pada tikus}

Tikus diinduksi menggunakan STZ dosis $45 \mathrm{mg} / \mathrm{kgBB}$ dalam buffer sitrat $\mathrm{pH}$ 4,5 secara intraperitoneal. Pengukuran kadar glukosa darah (KGD) dengan mengambil sampel darah tikus melalui plexus orbitalis. Sampel darah disentrifuge dan diambil serumnya untuk dicampurkan dengan reagen GOD FS yang kemudian dibaca hasilnya menggunakan 
biochemistry analyzer. Tikus dianggap diabetes jika KGD $\geq 250 \mathrm{mg} / \mathrm{dL}$ [11].

\subsection{Pembuatan Luka pada Tikus}

Rambut tikus pada bagian punggung dicukur hingga habis dan dibuat luka dengan diameter $5 \mathrm{~mm}$ menggunakan alat punch biopsy. Pembuatan luka diawali dengan anestesi menggunakan ketamin $0.2-0.3 \mathrm{~mL}$ secara intramuscular.

\subsection{Kelompok dan Perlakuan pada Tikus}

Pada penelitian ini digunakan 20 ekor tikus yang dibagi menjadi 4 kelompok masing-masing 5 ekor tikus. Empat kelompok terdiri dari 1 kelompok tanpa induksi diabetes dan 3 kelompok dengan induksi diabetes. Satu kelompok merupakan kontrol sehat tanpa pemberian topikal. Tiga kelompok lainnya adalah kontrol positif, dengan pemberian madecassol, kontrol negatif pemberian biocream, fraksi EA 10\% (dalam basis biocream). Aplikasi topikal pada luka dilakukan 2x sehari pagi dan sore sebanyak $25 \mathrm{mg}$ selama 10 hari.

\subsection{Pengamatan Makroskopis dan Mikroskopis Luka Diabetes Tikus}

Berat badan (BB) dan KGD tikus diamati sebelum dan setelah induksi STZ. Pegukuran diameter luka dimulai pada hari pertama tikus dieksisi, diukur menggunakan jangka sorong pada empat sisi diameter luka dan dirata-rata sehingga diperoleh persentase penutupan luka. Pengamatan dilakukan sampai hari ke-10. Tikus dikorbankan pada hari ke-11 dan jaringan kulit diambil untuk dibuat preparat histopatologi. Pengamatan mikroskopis berupa jumlah sel fibroblast dengan pewarnaan Hematoxyllin-Eosin.

\subsection{Analisis data}

Data yang diperoleh dianalisis dengan SPSS 16, uji normalitas data dengan Kolmogorov Smirnov (p>0,05), uji levene untuk mengetahui data homogen. Dilanjutkan dnegan uji One Way Anova $(\mathrm{p}<0,05)$ jika data normal. Jika data tidak normal diuji dengan uji non parametrik 2-independent sample test (Mann-Whitney Test).

\section{Hasil dan Pembahasan}

Uji KLT dilakukan untuk mengetahui senyawa apa yang terkandung dalam fraksi EA daun binahong. Hasil KLT menunjukkan bahwa fraksi EA daun binahong mengandung flavonoid dan polifenol.

\subsection{Pengamatan Makroskopis dan Mikroskopis Luka Tikus Diabetes}

Streptozotocin dapat menimbulkan kondisi diabetes dengan peningkatan KGD bertahap. Keberhasilan terjadinya diabetes tergantung dari beberapa faktor seperti strain, jenis kelamin, asupan pakan dan minum. Tikus jantan cenderung lebih rentan diinduksi streptozotocin [12]. Hasil rata-rata KGD tikus setelah diinduksi STZ pada kontrol negatif, kontrol positif, fraksi EA $10 \%$ pada hari ke-3 berkisar 292,8 $\pm 11,58$ hingga 336,17 $\pm 18,07$. Hal tersebut sesuai dengan teori yang menyebutkan bahwa KGD pada tikus lebih dari $250 \mathrm{mg} / \mathrm{dL}$ setelah 3 hari [11] dapat dikatakan diabetes. Pada kelompok kontrol sehat rata-rata KGD adalah 71,82 $\pm 2,12$, hal ini dikarenakan kontrol sehat tidak diinduksi STZ.

Tabel 1. Hasil Pengukuran Diameter Penutupan Luka Tikus Diabetes

\begin{tabular}{llll}
\hline Kelompok & Diameter Luka $(\mathrm{Cm})$ & \% Penutupan Luka \\
\hline & Hari ke- 1 & Hari ke-10 & \\
Kontrol Sehat & $0,400 \pm 0,000$ & $0,183 \pm 0,076$ & $54,17 \pm 19,09$ \\
Kontrol (-) & $0,50 \pm 0,038$ & $0,217 \pm 0,029$ & $57,48 \pm 2,75$ \\
Kontrol (+) & $0,450 \pm 0,050$ & $0,208 \pm 0,014$ & $53,33 \pm 5,77$ \\
Fraksi EA 10\% & $0,467 \pm 0,029$ & $0,217 \pm 0,029$ & $53,70 \pm 3,21$ \\
\hline
\end{tabular}

Dari tabel di atas dapat dilihat kontrol negatif memiliki persentase penutupan luka paling tinggi dibandingkan kelompok lainnya. Sementara untuk kelompok fraksi EA 10\% persentasenya paling kecil, sehingga dapat disimpulkan bahwa fraksi EA 10\% daun dinahong tidak memiliki aktivitas yang signifikan secara makroskopis dalam penutupan 
luka tikus diabetes.

Pemberian topikal fraksi EA daun binahong $10 \%$ berperan dalam memperpendek fase inflamasi dibanding kelompok diabetes lainnya (kontrol negatif dan kontrol positif). Jumlah fibroblast yang tinggi pada kelompok fraksi EA daun binahong $10 \%$ menunjukkan fase proliferasi yang masih terjadi. Adanya senyawa flavonoid dan polifenol berupa tanin di dalan fraksi EA daun binahong dapat membantu proses penyembuhan luka tikus diabetes melalui aktivitas antioksidan, antimikroba, adstringensia, dan antiinflamasi.

Tabel 2. Parameter Mikroskopis Jaringan Luka Kulit Tikus (X+SD)

\begin{tabular}{ll}
\hline Kelompok & Jumlah Fibroblast \\
\hline Kontrol Sehat & $113,87 \pm 26,14$ \\
Kontrol (-) & $79,53 \pm 30,10$ \\
Kontrol (+) & $82,07 \pm 33,05$ \\
Fraksi EA 10\% & $149,60 \pm 7,75$ \\
\hline
\end{tabular}

\section{Kesimpulan}

Fraksi EA daun binahong mengandung senyawa flavonoid dan tanin yang secara makroskopis tidak berpengaruh pada persentase penutupan luka. Secara mikroskopis berperan dalam meningkatkan jumlah sel fibroblast. Untuk itu perlu dilakukan penelitian lebih lanjut dengan peningkatakn konsentrasi fraksi dan para meter yang lebih luas agar aktivitas penutupan luka diabetes lebih maksimal.

\section{Ucapan Terima Kasih}

Penulis mengucapkan terima kasih kepada kepada Ditjen DIKTI, Farmasi Universitas Ahmad Dahlan dan STIKes Mitra Bunda Persada Batam, serta semua pihak yang telah membantu.

\section{Daftar Pustaka}

[1] Kruse, I. \& Edelman, S., 2006, Evaluation and Treatment of Diabetic Foot Ulcers, Clinical Diabetes 24(2).

[2] Singh, N., Amstrong, DG., Lipsky, DG., 2005, Preventing Foot Ulcers in Patient With Diabetes. JAMA 293(2), $217-228$.

[3] Bucala, Richard., Fibrocytes : circulating fibroblast that mediate tissue repair. 2004. http ://www.etrs.com

[4] Kottaimuthu, R., Ganesan, R. Dan Vijayan, R. 2011. Anredera cordifolia (Tenore) Stennis (Basellaceae) A New Record For India. ElixirBio Driver (40), 5517-5518.

[5] Aini, Q.S., 2014, Pengaruh Salep Ekstrak Daun Binahong (Anredera cordifolia (Ten.) Steenis) terhadap Pembentukan Jaringan Granulasi pada Luka Bakar Tikus Sprague dawley (Studi Pendahulua Lama Paparan Luka Bakar 30 detik dengan Plat Besi), Skripsi, Program Studi Pendidikan Dokter, Fakultas Kedokteran dan Ilmu Kesehatan Universitas Islam Negeri Syarif Hidayatullah, Jakarta.

[6] Marinton, S., 2015, Uji Aktivitas Antimikroba Ekstrak Etanol Daun Binahong Anredera cordifolia) terhadap Staphylococcus aureus dan Escherichia coli secara In Vitro (Skripsi), Universitas Muhammadiyah Malang, Malang. Viewed from https://core.ac.uk/download/pdf/33336454.pdf.

[7] Kintoko \& Desmayanti, A., 2016, The effectivity of ethanolic extract of binahong leaves (Anredera cordifolia (tenore) steen) gel in the management of diabetic wound healing in aloxan-induced rat models, Jurnal Kedokteran Dan Kesehatan Indonesia7(5), 227-236.

[8] Ekaviantiwi, T. A., 2013, Identifikasi Asam Fenolat dari Ekstrak Etanol Daun Binahong (Anredera cordifolia (Ten.) Stennis) dan Uji Aktivitas Antioksidan, Chem Info Journal1(1), 283-293.

[9] Salimi, Y., Bialangi, N. \& Tomayahu, R., 2014, Identifikasi Senyawa Aktif dan Uji Toksisitas Ekstrak Daun Binahong (Anrederacordifolia (Ten). Steenis) Dengan Metode Brine Shrimp Lethality Test (Bsit), Seminar Nasional Kimia \& Pendidikan Kimia Ung 201429.

[10] Harborne, J.B., 1987, Metode Fitokimia, Terjemahan dari Phytochemical Methods oleh Kosasih Padmawinata \& Iwang Soediro,Institut Teknologi Bandung, Bandung.

[11] Koneri, R., Samaddar, S., Simi, S., Rao, S., 2014, Neuroprotective effect of a triterpenoid, saponin isolated from Momordica cymbalaria Fenzl in diabetic peripheral neuropathy, Indian Journal Pharmacol 46 (76).

[12] Deeds, M. C., Anderson, S. M., Amstrong, A. S., Gastineau, D. A., Hiddinga, H. J., Jahangin, A., Eberhardt, N. L., \& Kudva, Y. C., 2011, Single Dose Streptozotocin Induced Diabetes : Considerations For Study Design in Islet Transplantation Models, Lab Anim 45(3), 131-140.

[13] Thakur, R., Jain, N., Pathak, R. \& Sandhu, S. S., 2011, Practices in wound healing studies of plants, Evidence-Based Complementary and Alternative Medicine 2011. 